\title{
THE "INDIRECT" OR "CONCEPTUAL" EVOCATION OF A PROTECTED DESIGNATION OF ORIGIN AND ITS PRACTICAL AND JURIDICAL EFFECT AFTER ECJ CASE QUESO MANCHEGO
}

\author{
VITO RUBINO' \\ Università del Piemonte Orientale \\ vito.rubino@uniupo.it
}

Cómo citar/Citation

Rubino, V. (2019).

The "indirect" or "conceptual" evocation of a protected designation of origin and its practical and juridical effect after ECJ case Queso manchego. Revista de Derecho Comunitario Europeo, 64, 963-979. doi: https://doi.org/10.18042/cepc/rdce.64.06

\begin{abstract}
This commentary on the EU Court of Justice Queso Manchego ruling analyses the evolution of the concept of "evocation" of a PDO-PGI in order to highlight its expansive character and its consequences for economic operators and national courts (called upon to apply EU legislation in this area).

In particular, the author, after having reconstructed the most significant EU case-law on the subject in the last twenty years, focuses on the concept of "indirect evocation" and the "average European consumer" of reference, concepts analysed in detail by the Queso Manchego judgment. The evolutionary dynamics of the matter
\end{abstract}

1 Research Fellow of European Union Law, University of East Piedmont, Italy. Orcid-id 000-001-8143-7797. Research field: food law, IP rights, protected GIs. 
are then compared with what happened in the sector of well-known brands in order to understand similarities and differences between this industrial property rights, and forecast what further developments may take place.

Finally, the author points out the problem of the difficult balance between the requirements of protection, based on the full ownership of the known brand, and fundamental freedoms (economic, competitive, expressive), which it will necessary for national courts to uphold in the context of future cases.

\section{Keywords}

Geographical indications; protected denominations of origin; evocation; trademarks; unfair competition.

\section{LA EVOCACIÓN «INDIRECTA»O «CONCEPTUAL»DE UNA DENOMINACIÓN DE ORIGEN PROTEGIDA Y SUS CONSECUENCIAS PRÁCTICAS Y JURÍDICAS TRAS EL FALLO DEL TJUE EN EL ASUNTO QUESO MANCHEGO}

\section{Resumen}

Este comentario sobre el fallo Queso Manchego del Tribunal de Justicia de la Unión Europea analiza la evolución del concepto de «evocación» de una DOP-IGP para resaltar su carácter expansivo y sus consecuencias para los operadores económicos y los tribunales nacionales (llamados a aplicar la legislación de la UE en esta área).

En particular, el autor, después de haber reconstruido la jurisprudencia más relevante de la UE sobre el tema en los últimos veinte años, se centra en el concepto de «evocación indirecta» y sobre el "consumidor europeo medio» de referencia, conceptos analizados en detalle en la sentencia del Queso Manchego. La dinámica evolutiva del asunto se compara con lo que sucedió en el sector de marcas conocidas para comprender las similitudes y diferencias entre los casos, y prever qué desarrollos ulteriores podrían darse.

Por último, el autor pone una especial atención en el problema del difícil equilibrio - que los tribunales nacionales deberán mantener en el contexto de futuras controversias - entre los requisitos de protección, basados en la plena propiedad de la marca conocida, y las libertades fundamentales (económicas, competitivas, de expresión).

\section{Palabras clave}

Indicaciones geográficas; denominaciones de origen protegidas; evocación; marcas comerciales; competencia desleal. 


\section{L'EVOCATION «INDIRECTE»OU «CONCEPTUELLE» D'UNE INDICATION GÉOGRAPHIQUE PROTÉGÉE ET SES CONSÉQUENCES PRATIQUES ET JURIDIQUES APRÈS LA SENTENCE DE LA COUR DE JUSTICE DE L'UE SUR QUESO MANCHEGO}

\section{Résumé}

Ce commentaire de l'arrêt Queso Manchego de la Cour de justice de l'Union européenne analyse l'évolution de la notion d' «évocation» d'une AOP-IGP pour mettre en lumière son caractère expansif et les conséquences qui en découlent pour les opérateurs économiques ainsi que pour les juridictions nationales (appelées à appliquer la réglementation européenne en la matière). Après avoir reconstitué la jurisprudence la plus significative de la Cour de justice sur le sujet au cours des vingt dernières années, l'auteur se penche sur le concept d' «évocationindirecte» et sur le «consommateur moyen européen» de référence, concepts analysés en détail par l'arrêt Queso Manchego. La dynamique évolutive de la matière est ensuite comparée à ce qui s'est passé dans le domaine des marques notoires, en vue de comprendre les similitudes et les différences entre ces droits de propriété industrielles et envisager quels développements futurs pourront en résulter.

Enfin, l'auteur souligne le problème de l'équilibre difficile existant entre les exigences en matière de protection, privilégiant la protection absolue de la marque notoire, et les libertés fondamentales (économique, de concurrence, d'expression), qu'il appartiendra aux juridictions nationales de réaliser dans le cadre des cas qui se présenteront à l'avenir.

\section{Mots clés}

Indications géographiques; dénominations d'origine protegées; évocation; marques; concurrence déloyale. 


\section{CONTENTS}

I. INTRODUCTION. II. THE DISPUTE IN THE MAIN PROCEEDINGS. III. THE NOTION OF "EVOCATION" IN THE CASE-LAW OF THE EUROPEAN COURT OF JUSTICE AND IN THE QUESO MANCHEGO CASE. IV. THE "AVERAGE EUROPEAN CONSUMER". V. FINAL REMARKS. BIBLIOGRAPHY.

\section{INTRODUCTION}

The judgment of the EU Court of Justice dated 2 May, 2019 on the protection of the denomination Queso Manchego ${ }^{2}$ is the final step in a long process of EU case-law which, starting with the well-known Cambozola case ${ }^{3}$, has defined, over the last 20 years, the limits of the protection of geographical indications of quality foodstuffs in the European Union through the concept of "evocation".

From a juridical point of view, the ruling on the Queso Manchego case is particularly relevant for the clarity of its contents - which bring together the most relevant positions of the Court on this issue - and for the systematic reconstruction of the reference standards. At the same time, the expansion of the notion of "evocation" leaves unresolved the question of the balance between competition and the protection of the public interests underlying the standard (in particular consumer protection and the development of the Common Agricultural Policy) in the ambit of the European protection of geographical designations.

It is, therefore, definitely interesting to summarise the contents of the Court's ruling in order to evaluate its consequences in terms of legal and commercial relations between PDO and PGI products and similar generic products.

2 See the judgment of the Court of Justice of the European Union dated 2 May 2019, Fundación Consejo Regulador de la Denominación de Origen Protegida Queso Manchego vs. Industrial Quesera Cuquerella SL e Juan Ramón Cuquerella Montagud, case C-614/17, EU:C:2019:344.

3 See the judgment of the Court of Justice of the European Union dated 4 March 1999, Consorzio per la tutela del formaggio Gorgonzola vs. Käserei Champignon Hofmeister GmbH \& Co. KG and Eduard Bracharz GmbH, case C-87/97, EU:C:1999:115. 


\section{THE DISPUTE IN THE MAIN PROCEEDINGS}

The dispute which resulted in a preliminary ruling on the matter arose from an action brought by the Fundacion Consejo Regulador de la Denominacion de Origen Protegida Queso Manchego to ascertain that the company Industrial Quesera Cuquerella SL, with a production facility in the Spanish region of Castilla-La Mancha, was not entitled, in the labelling, presentation and advertising of its dairy products, to use various indirect conceptual references to the geographical indication "Manchego/La Mancha" protected in the European Union as a PDO in the "cheese" category.

In particular, the use of terms and figures from the well-known literary work Don Quijote de la Mancha was disputed (such as, for example, the name Rocinante, the use of archaic terms like "adorga" and other references from Cervantes's novel ${ }^{4}$, including landscapes with windmills and sheep in the background of the labels, clearly related to the places where the novel was set).

The Fundacion's claims were rejected both by the local Tribunal and the Court of Appeal on the grounds that the symbols and names in question were not sufficiently similar, under a phonetic and visual point of view, to the toponym Queso Manchego or La Mancha.

The local Courts stated, also, that the geographical references at issue could have been associated just to the well-known region of Spain where the producer was based, and not necessarily to the typical cheese product protected by the European Union.

The Foundation (Consejo Regulador), therefore, brought an appeal action before the Tribunal Supremo, asking, inter alia, for protection granted by the "evocation" rule pursuant to EU Regulation 510/06 on PDOs-IGPs ${ }^{5}$ (applicable to the ratione temporis event, today EU Reg. 1151/20126), also in the case of the registered toponym not being used explicitly to designate a generic product.

The result was the formulation of three preliminary questions to the Court of Justice of the European Union on the extension of the concept of "evocation" and on the characteristics of the average consumer to be considered when assessing the possible evocative nature of the labels in question.

\footnotetext{
4 See, for example, the archaic term "adorga" to indicate Don Quijote's shield.

5 See Council Regulation (EC) No 510/2006 dated 20 March 2006 on the protection of geographical indications and designations of origin for agricultural products and foodstuffs, in OJL 93, 31.3.2006, p. 12 ff., repealed by the Regulation (EU) No. 1151/2012 of the European Parliament and of the Council dated 21 November 2012 on quality schemes for agricultural products and foodstuffs, in OJ L 343, 14.12.2012, p. 1

6 See footnote no. 3.
} 


\section{THE NOTION OF "EVOCATION" IN THE CASE-LAW OF THE EUROPEAN COURT OF JUSTICE AND IN THE QUESO MANCHEGO CASE}

The first two preliminary questions can be considered together, since both of them essentially concern the scope of the legal institution under discussion.

As is well known, the European regulations on quality foodstuffs ${ }^{7}$ provide registered toponyms with protection against their direct or indirect use by non-legitimate entities, or against the usurpation, imitation or evocation of the geographical indication in question (even if the true origin is specified or the label contains an expression such as "type", "method", "in the manner", etc.).

The rules under examination contain, also, a final clause against "any other practice liable to mislead the consumer as to the true origin of the product" (see, as an example, Art. 13 (2) (g) of the EU regulation 1151/2012).

With specific reference to the EU case-law related to "evocation", it should be first of all underlined that previous judgments generally originated from cases where the trade name of the contested generic product included a part of the protected toponym?

7 The protection of registered geographical indications is currently governed by Art. 13 of the EU Regulation No. 1151/2012 of the European Parliament and of the Council of 21 November 2012 on quality schemes for agricultural products and foodstuffs cit. with regard to foodstuff other than wines and spirit drinks, which corresponds to Art. 20 of the Regulation No. 251/2014 of the European Parliament and of the Council of 26 February 2014 on the definition, description, presentation, labelling and the protection of geographical indications of aromatised wine products (OJ L 84 of 20 March 2014, p. 14 ss.); Art. 103 of the Regulation No 1308/2013 of the European Parliament and of the Council of 17 December 2013 establishing a common organisation of the markets in agricultural products (OJ L 347 of 20 December 2013, p. 671 ff.); Art. 16 of the Regulation (EC) No. 110/2008 of the European Parliament and of the Council of 15 January 2008 on the definition, description, presentation, labelling and the protection of geographical indications of spirit drinks (OJ L 39 of 13 February 2008, p. 16 ff.). For a general overview of the EU protection of geographical indications see Cortés Martín (2003), Evans (2010), Fontaine (2014), and Calboli (2015).

8 See footnote no. 6.

9 See the well-known cases Cambozola (judgment of the Court of Justice of the European Union of 4 March 1999, Consorzio per la tutela del formaggio Gorgonzola vs. Käserei Champignon Hofmeister GmbH \& Co. KG and Eduard Bracharz GmbH, cit.), considered by the Court an evocation of the protected geographical name Gorgonzola PDO; Verlados (ECJ judgment of 21 January 20016, Viiniverla Oy v Sosiaali- ja terveysalan lupa- ja valvontavirasto, case C-75/15, EU:C:2016:35), considered 
The Court's judgments were, therefore, largely focused on the ability of these generic names to trigger in the mind of the consumer an association with the registered toponyms. Thus, for example, in the Cambozola leading case, the Court held that the ending "zola" was evocative of the name Gorgonzola PDO, basing its evaluation on the "phonetic" similarity and supporting its opinion also with some reinforcing elements, such as, for example, the morphology of the product, the blue-veined nature of the cheese and other factors (used, however, in a complementary way and not as an essential part of the judgment on the phonetic evaluations).

The uniformity of following judgments on the issue appeared to require the presence, at least in part, of elements of the protected geographical indication in the trademark or name of the generic product in order to have an "evocation" from the juridical point of view.

This interpretation of the rule was also favoured by the structure of the rule (Art. 13 Reg. 510/06 and ff. mod.) where "evocation" is positioned alongside the other formal infringements of the protected geographical indications (such as imitation, misuse etc.), while a specific prohibition of misleading practices regarding the true origin of the product and its authenticity is contained only in the last comma of the rule in question.

In other words, it seemed that the aping of a protected geographical name was not covered by "evocation", rather being related to the provision of misleading practices contained in the closing paragraph of the EU rule under examination (which implies a concrete risk of confusion), or, more in general, to the rules on unfair competition, content in the general regulation on food information to consumers (see Reg. 1169/2011/EU), and, in particular, in its Art. 7 dedicated - inter alia - to the parasitic exploitation of reputation of well-known products in competition ${ }^{10}$.

an evocation of Calvados PDO; Toscoro (see the Judgment of the General Court 2 February 2017, Roberto Mengozzi vs. European Union Intellectual Property Office, EU:T:2017:54) evocation of Olio Extravergine di oliva Toscano PGI. On the notion of "evocation” see Gangjee (2007), Gonzalez Vaqué (2008), Medina González (2012), Martínez Gutiérrez (2014), Paganizza (2015), Coppola (2016), and Rubino (2017:326 ff).

10 See Art. 7 of the EU Regulation no. 1169/2011 of the European Parliament and the Council on the provision of food information about foodstuff vit., according to which "food information shall not be misleading, particularly: (a) as to the characteristics of the food and, in particular, as to its nature, identity, properties, composition, quantity, durability, country of origin or place of provenance, method of manufacture or production; (b) by attributing to the food effects or properties which it does not possess; (c) by suggesting that the food possesses special characteristics when in fact 
In 2018, the Court made a first fundamental change to the issue by introducing into the evocation paradigm elements other than the pre-eminent semantic assessment of conflicting terms ${ }^{11}$.

The case referred for a preliminary ruling concerned the marketing of a whisky called Glen Buchenbach, made in Germany, the label of which did not show any express reference - not even partial - to the name Scotch Whisky, protected at EU level.

However, the Scotch Whisky Association, which is responsible for protecting the PDO by law, took the view that the term "glen" (used in the Scottish language instead of the term "valley") was sufficiently allusive to the origin of the product to trigger a mental link between the protected PDO and the generic product in question ${ }^{12}$.

The dispute before the Scottish court resulted in a series of questions to the EU Court for a preliminary ruling, essentially aimed at distinguishing between the concept of "indirect use" of the registered toponym and the notion of "evocation".

The Court, upholding the innovative approach of the Advocate Gener$\mathrm{al}^{13}$, stated that, although the partial integration of a toponym registered in the disputed mark represents the most recurrent case of evocation, it is not an essential precondition for an evocation under the EU Regulations on GIs protection.

According to the EU Judges, in fact, the phonetic/visual similarity between the conflicting marks is only one of the criteria which the national courts must assess in order to establish or exclude the existence of an evocation.

In fact, the decision should be taken considering the "conceptual" proximity between the figurative signs at issue in the main proceedings, taking in

all similar foods possess such characteristics, in particular by specifically emphasising the presence or absence of certain ingredients and/or nutrients; (d) by suggesting, by means of the appearance, the description or pictorial representations, the presence of a particular food or an ingredient, while in reality a component naturally present or an ingredient normally used in that food has been substituted with a different component or a different ingredient".

11 See the ECJ judgment 7 June 2018, Scotch Whisky Association vs. Michael Klotz, case C-44/17, EU:C:2018:415, on which Mantrovs (2018), Brüß (2018).

12 See footnote no. 5. In particular, the labelling of the product showed the following indications: Waldhornbrennerei (Waldorn distillery); Glenbuchenbach, Swabian Whisky (Single malt Whisky of Sweden); Deutsches Erzeugnis (German quality product); Hergestellt in der Berglen (produced in Berghen).

13 See the opinion of Advocate General Saugmandsgaard Øe, delivered on 22 February 2018, EU:C:2018:111. 
consideration all the relevant elements, such as the presentation, the commercial name, the use of trademarks, the image of the product, and, as a consequence, whether it can trigger a mental association to the original PDO-PGI product in the mind of an European average consumer.

In other words, the concept of evocation is not incompatible with the absence of an explicit (even partial) use of the protected name, as long as, from the actual circumstances, it is possible to derive a speculative link between the generic product and the PDO-PGI.

In the Queso Manchego judgment, here in comment, these statements are confirmed and - if possible - are even more explicit.

According to the Court, in fact, Art. 13 of EC regulation 510/06, in so far as it provides for protection against "any evocation" (even where the protected name is accompanied by expressions such as "kind", "type", "method", "imitation", etc.) does not intend limiting in any way the conduct which can be traced back to this rule, since what the standard protects is ultimately the consumer's interest to have "clear, succinct and credible" information on the product on sale (see point 29 of the judgment) and, of course, the integrity of the PDOs-PGIs as instruments of agricultural policy for improving the income of the populations of the places of production.

A broad interpretation of the notion of evocation, therefore, makes it easier to achieve the targets of the European Legislator, thus including the prohibition of the use of images, drawings and anything else that could even conceptually trigger a mental association between products which the law aims to prevent.

The Court, therefore, confirms an interpretation of evocation which is strongly inspired by public interest, that could have a significant impact, in the future, on competition between similar-generic products and products with protected names. The purpose of protecting a fair communication for the consumer, in fact, tends to expand the sphere of evocation, and can lead to various interpretations of the rule in the future, depending on the evaluation of the judge regarding consumer behaviour.

In the same direction, the judgment also addresses the second issue relating to the freedom of communication of producers located in the same territory of the PDO-PGI.

According to the Court, in fact, the EU regulations on GIs protection do not provide for any exception authorising voluntary information in the labelling on the place of production of the generic foodstuff that can potentially conflict with the registered toponym, even if the message may be true in fact.

Such a practice would end up justifying an unfair competitive edge on the part of local producers of generic foodstuffs, since it would inevitably lead 
to trigger a link with the reputation of the protected geographical name on the part of local products which do not comply with the PDO scheme.

\section{THE "AVERAGE EUROPEAN CONSUMER"}

In the light of the foregoing, the Court also addresses the third issue referred for preliminary ruling concerning the parameter of the "average consumer" on which the judge should base his assessment of the evocative nature of the commercial communication under examination.

The Queso Manchego judgment confirms, in this regard, first of all, the need for the national Courts to carry out their assessments taking account of the "average European consumer", that is to say, a reasonably well-informed and attentive person who incorporates the different national sensitivities in an increasingly global and open market ${ }^{14}$.

In Viinverla ${ }^{15}$ the EU Court underlined the need to ensure uniform protection for PDOs-PGIs throughout the EU by assessing the impact of the communication message on the various markets in the EU Member States: in other words, the psychological effect of evocation should be predicted with due regard to the different degrees of consumer confidence in the typical product in the various Member States.

In the case here under examination the Court has, moreover, specified that the "uniform" nature of the protection does not exclude evocation where the risk of "mental association" between the products depends on specific national cultural sensitivities.

The protection afforded by the EU legislation in question protects both from the exception relating to the lesser sensitivity of certain peoples regarding the semantic value of certain names ${ }^{16}$, and the exact opposite, i.e. where

14 About this concept, among others, González Vaqué (1999), Micklitz, Reich, Rott and Tonner (2014).

15 See the ECJ, 21 January 20016, Viiniverla Oy v Sosiaali-ja terveysalan lupa-ja valvontavirasto, cit.

16 See, as an example, the Parmesan case (ECJ judgment 26 February 2008, Commission of the European Communities vs. Federal Republic of Germany, case C-132/05, in Report cases, 2008, p. I-00957 ff.) where the main defensive argument was based on the opinion of German consumers about the "generic" meaning of the term "Parmesan" (understood as being synonymous with grating cheese and not as a typical Italian cheese). See, on this point, Hauer (2008) and Heath (2008). 
generic products are parasitically attached with regard to specific local cultural traditions in order to exploit their market appeal ${ }^{17}$.

In this way, the task of the national judge becomes particularly delicate and complex.

In his evaluations, the judge will have to take into consideration a very wide series of factors, in order to construct a parameter of assessment that does not refer to a monolithic and abstract cosmopolitan consumer that includes in itself all the national attitudes, but a plurality of persons, with their cultural specificities and national sensitivities.

\section{FINAL REMARKS}

In the light of the summarized elements, it seems possible to make some remarks with regard to the juridical and practical consequences of the judgment Queso Manchego and its influence on the future case-law of the European Court of Justice related to PDO-PGI protection issues.

From the juridical point of view, the most significant result of this judgment seems to be the definitive confirmation that consumer protection is the principal key for the interpretation of the European rules on protection of geographical indications.

In fact, the Court resolves the latent conflict between freedom of competition, fundamental rights of the producers and the protection of the underlying public interests through the principle of the effet utile, taking as a priority the protection of right of consumers to a clear, succinct and credible information regarding the origin of the product.

This criterion seems to be the keystone of the juridical construction under examination and could also be the answer to further pending preliminary rulings.

In fact, the increasing protection of PDO-PGI in order to safeguard public interests can have a significant impact on the marketing relationships with regard to this specific ambit of the Single Market. It can also determine a remarkable limitation of the rights of business operators who are not part of the PDO scheme.

The question is not so much the evaluation of the fairness of suggestive advertising, where the parasitic nature of the approach makes evident the

17 In Queso Manchego the Commission has underlined that not all European consumers are acquainted with the characters from Cervantes' novel, and, in any case, that the sensitivity for these topics could be different from State to State. 
need to defend the primacy of quality product and, of course, the need for a full protection of their geographical names.

The most critical aspect is, rather, the problem of the freedom of expression of producers who are based in the same territory as a PDO-PGI, which can collide with such a strict interpretation of the rules in question.

According to the Court, in fact, the EU regulations do not provide any specific exception to the "evocation rule", because, otherwise, this could create an unfair advantage for those producers based in that territory but who do not take part in the PDO-PGI scheme. Thus, under the radar, the Court takes for granted that the PDOs-PGIs have a sort of cultural/semantic/communicational priority (or supremacy) with regard to the territory, so that any reference to its geographical indication - even if true — should be considered in the light of evocation.

This point reveals the Court's balancing approach to some of the most important "constitutional rights" of the EU legal order in this field: competition (upon which the internal market was built according the liberal view of the European intergration) and the new fundamental values, among which — with specific regard to the market regulation — the expectations and rights of consumers.

In fact, starting from the presumption that the registration of a PDOPGI creates itself a risk of confusion with regard to any reference to the territory in the labelling of simil-generic products, the Court's objective of protecting quality schemes ends up overcoming private interests at stake.

Moreover, we are not witnessing a change of priorities in the Community legal order: there are not two opposite values at stake, but, the same principle in its modern evolution.

In fact the European competition law has itself evolved adsorbing issues such as consumer protection, clarity of information and freedom of choice in the market.

If, therefore, the current competition paradigm cannot ignore the real driving force in the marketplace (namely, the final purchaser of goods and services), the "useful effect" principle should be focused on the consumer's freedom of choice. Thus the practical application of this principle (the so-called "proportionality") should be used by national judges in order to guarantee consistency in the application of the rules in discussion.

Therefore, the extension of the notion of "evocation" to all parasitic marketing approaches (such as "aping", conceptual references, allusions and any other unfair practice that can influence consumer behaviour and choice) offers a better protection to PDO products and to the autonomy/freedom of the targets of commercial communication, in line with the parallel legislation and 
case-law ${ }^{18}$ on the protection of the so-called "well-known" trademarks, where protection includes the mere "risk of association" between signs/symbols/designations of the competing product and the registered industrial property right, as well as any conflictual use of the mark (trade name or trademark, as the case may be) which permits obtaining an "unfair competitive edge from the distinctive character or the reputation" of the imitated mark ${ }^{19}$.

By applying the same criteria (precaution in order to guarantee the best level of consumer protection) to the definition of the boundaries of the issue, the outcome will be the necessity to relate all the implementation rules to the expressed principle ${ }^{20}$.

18 For a regulatory perspective, see Regulation (EU) no. 2017/1001 of the European Parliament and of the Council of 14 June 2017 on the European Union trade mark, in OJ L 154, 16.6.2017, p. 1 ff., and the directive (EU) no. 2015/2436 of the European Parliament and of the Council of 16 December 2015 to approximate the laws of the Member States relating to trade marks, in OJ L 336, 23.12.2015, p. $1 \mathrm{ff}$. With regard to the ECJ case-law, see, as an example, the judgments of the Court 18 June 2009, L'Oreal SA, Lancome parfums and Laboratorie Garnier \& Cie vs. Bellure NV at al., case C-487/07, EU:C:2009:378, points 36 - 45. See also, to that effect, the judgments of the Court of 22 June 2000, Marca Mode CV vs. Adidas AG e Adidas Benelux BV, Case C-425/98, ECR I-4861; 23, October 2003, Adidas-Salomon and Adidas Benelux, Case C-408/01, EU:C:2003:582; 10 April 2008, Adidas and Adidas Benelux, Case C-102/07, EU:C:2008:217, 27 November 2008, Intel Corporation Inc. vs. CPM United Kingdom Ltd, Case C-252/07, EU:C:2008:655.

19 See, in particular, Art. 10 par. 2 of the Directive 2015/2436 and Art. 9 of the Regulation, according to which "where the risk exists that the packaging, labels, tags, security or authenticity features or devices or any other means to which the mark is affixed could be used in relation to goods or services and such use would constitute an infringement of the rights of the proprietor of an EU trade mark under Article 9(2) and (3), the proprietor of that trade mark shall have the right to prohibit the following acts if carried out in the course of trade: (a) affixing a sign identical with, or similar to, the EU trademark on packaging, labels, tags, security or authenticity features or devices or any other means to which the mark may be affixed; (b) offering or placing on the market, or stocking for those purposes, or importing or exporting, packaging, labels, tags, security or authenticity features or devices or any other means to which the mark is affixed".

20 So, for example, in the Case C-569/18 Caseificio Cirigliana Srl and Others v Ministero delle Politiche Agricole, Alimentari e Forestali and Others, case C- 569/18, the ECJ had to decide if Arts. 3, 26, 32, 40 and 41 of the TFEU and Arts. 1, 3, 4, 5 and 7 of Regulation 1151/2012/EU on the Protected Designation of Origin, which require Member States to guarantee both free competition in respect of goods within the European Union and protection for quality schemes to support less favoured agri- 
Certainly, the practical implication of this approach is a significant risk of a progressive "closure" of the PDO chain, that is a strict separation of the production chains and the creation of a market sector dedicated to quality products that is increasingly detached from the competing generic products.

From the "communication" point of view this effect is aggravated by the growing unpredictability of the evocation judgment, considering that the factual elements (left to the opinion of national judges) are largely outweighing the juridical elements (such as the incorporation of a protected part of the toponym in the generic denomination/private trademark, the generic nature of the term used by the competitor etc.).

So, in the end, the progressive expansion of the notion of "evocation" should lead the producers of similar-generic products to a sort of self-discipline marketing approach, in order to limit the mental association between elements of their communication with the reputation of the protected geographical indication, and this approach — sooner or later — leads to a separation of the two markets.

While, in fact, the solution put forward by the Court does not rule out that, in the judgment on evocation, the national court may save certain elements of the labelling, presentation or advertising of the generic product, because they are true or in any event not sufficiently unambiguous to determine the mental association between products ${ }^{21}$, the acceptance by the assessment

cultural areas, should be interpreted as precluding a restriction being imposed under national law (Art. 4 of Decree Law No. 91 of 24 June 2014, as converted into law by Law No. 116 of 11 August 2014) on the production of PDO Mozzarella di Bufala Campana, which is to be made in factories dedicated exclusively to such production, in which the holding and storage of milk originating from farms not included in the monitoring system for PDO Mozzarella di Bufala Campana is prohibited. The Court stated that a measure of this kind can be justified because of the risk of fraud (mixing of different types of milk during the production process) and it is coherent with the request of reliability of the PDO scheme by the consumer (see points 35-44). Under this point of view, the Court's case-law on the competition between PDO-PGI and generic products seems to be inspired by the same scale of priorities (consumer protection; expansion of the quality of products within the framework of the common agricultural policy etc.), and, of course, the solution to Queso Manchego is consistent with this setting of values.

21 See, as an example, the Judgment of the General Court of Cagliari (Italy), 31 May 2014, Case No. 1363/2014, with regard to a cheese named Pecorino (which, of course, is a generic name that means "sheep-cheese") labelled with some commercial claims related to the origin of the milk, the place of production and the characteristics (flavour, taste and so on) indirectly connected to the island of Sardinia, 
of heterogeneous factors such as the shape and morphology of the products, the graphics of the communication, the indirect conceptual elements etc., in the absence of the direct use of the toponym, makes advertising in this market environment particularly insidious.

For this reason national judges should approach with a great deal of caution the factual evaluation between lawful information to consumers regarding the characteristics of the products on the market and the possible breach of the conceptual limit of the indirect "parasitic exploitation" of the PDO - PGI reputation ${ }^{22}$.

This is also the reason why the Court urged a wider use, in the future, of the preliminary ruling instrument, according Art. 267 TFEU, in order to ensure the overall consistency of national decisions ${ }^{23}$, avoiding excessive fragmentation of judgments due to different national sensitivities.

which is also the geographical term protected in PDO Pecorino Sardo. The specific claim was: "The C.T. Pecorino is produced using only sheep's milk and, after three weeks of maturing, it reaches its typical sweet and intense taste, that captures the flavour of its Land of origin: Sardinia". The Court dismissed the case stating that this kind of commercial claims are not "evocations" in the technical sense of the rule.

22 A too extensive use of the notion of "indirect evocation" could lead, in fact, to the transformation of geographical indications in a sort of monopoly of the product/ scheme, which is probably not in line with the goals of the EU regulations under examination according to the well-known Cognac judgment (see ECJ, 14 July 2011, Bureau national interprofessionel du Cognac vs. Gust. Ranin Oy, joined cases C-4/10 and C-27/10, in Report, 2011, p. I-06131 ff., in which the Court stated that competition between generic products and PDO foodstuff is desirable). An overestimation of the factual elements could not be useful for the real goal of Queso Manchego judgment, which is the fight against the commercial parasitism. In this sense, it might be useful that the guiding criterion of this delicate assessment not be simply objective (i.e. the hypothetical reactions of the average consumer, as stated by the Court), but, include also the evaluation of the approach of the competitor producer, in order to assess the effective "parasitic" nature of the communication under examination. The identification of speculative intentions, together with the assessments of the impact of the communication on the average European consumer, could, in fact, lead to balanced solutions on a case by case basis, distinguishing the elements of marketing that maliciously try to generate the association of products to exploit the PDO-PGI from what is simply an expression of the need to provide the consumer with the elements of assessment of the product on the market, albeit possibly in competition with a PDOPGI.

23 See point 37 of the judgment, and ivi cit., ECJ 10 September, 2009, Severi, case C-446/07, ECLI:C:2009:530, point 60. 


\section{Bibliography}

Brüß, M. (2018). "Glen Buchenbach": CJEU further clarifies the system of prohibited acts with regard to geographical indications. European Intellectual Property Review, 746-750.

Calboli, I. (2015). Geographical Indications of Origin at the Cross Roads of Local Development, Consumer Protection and Marketing Strategies. IIC-International Review of Intellectual Property and Competition Law, 46 (7), 760-780. Available at: https://doi.org/10.1007/s40319-015-0394-0.

Coppola, N. (2016). Viinverla: too much 'ado' about nothing. Journal of Intellectual Property Law and Practice, 11 (6), 406-408. Available at: https://doi. org/10.1093/jiplp/jpw046.

Cortés Martín, J. M. (2003). La protección de las indicaciones geográficas en el comercio internacional intracomunitario. Madrid: Ministerio de Agricultura, Pesca y Alimentación.

Evans, G. (2010). The Comparative advantages of Geographical Indications and Community Tarde Marks for the Marketing of Agriculture Products in the European Union. IIC-International Review of Intellectual Property and Competition Law, 29 (1), 224-260. Available at: https://doi.org/10.1093/yel/29.1.224.

Fontaine, B. (2014). The Present and the Future of the Interaction Between Trade Marks and Geographical Indications in Community Law. ERA-Forum, Scripta iuris Europaei, 15 (2), 183-196. Available at: https://doi.org/10.1007/s12027014-0347-y.

Gangjee, D. (2007). Say Cheese: A Sharper Image of Generic Use through the Lens of Feta. European Intellectual Property Review, 5, 172.

González Vaqué, L. (1999). La noción de consumidor normalmente informado en la jurisprudencia del Tribunal de Justicia de las Comunidades Europeasla: la Sentencia Gut Springenheide. Derecho de los Negocios, 10 (103), 1-15.

Gonzalez Vaqué, L. (2008). Alcance de la protección de una denominación de origen registrada frente a su utilización abusiva. Revista de Derecho Comunitario Europeo, 30, 545.

Hauer, C. (2008). Using the Designation "Parmesan" for Hard Cheese (Grated Cheese) of Non Italian Origin. European Food and Feed Law Review, 3, 387.

Heath, C. (2008). Parmigiano Reggiano by Another Name - The ECJ's Parmesan Decision. International Review of Intellectual Property and Competition Law, 951-962.

Mantrovs, V. (2018). Do you prefer Scotch or German whisky?: CJEU judgment in the Scotch Whisky and Glen Buchenbach dispute. European Journal of Risk Regulation, 9 (4), 719-729. Available at: https://doi.org/10.1017/err.2019.1.

Martínez Gutiérrez, A. (2014). Infracción de las Denominaciones Geográficas Protegidas a través de conductas evocativas: un apunte crítico. Rivista di Diritto Alimentare, 4, 37-48. Disponible en: http://www.rivistadirittoalimentare.it. 
Medina González, M. A. (2012). Protection of Geographical Indications against Translation, against Generic Use, Evocation and Other Potential Enemies. Journal of Intellectual Property Law and Practice, 7 (1), 20-22. Available at: https://doi.org/10.1093/jiplp/jpr182.

Micklitz, H. W., Reich, N., Rott, P. and Tonner, K. (eds.) (2014). European Consumer Law. Cambridge: Intersentia Ltd.

Paganizza, V. (2015). More Holes tha Cheese: PDOs, Evocation and a Possible Solution. European Food and Feed Law Review, 10, 222.

Rubino, V. (2017). From "Cambozola” to "Toscoro": the difficult distinction between "evocation" of a protected geographical indication, "product affinity" and misleading commercial practices. European Food and Feed Law Review, 12 (4), 326-334. 